\title{
GEOGRAPHICAL DISTRIBUTION AND STATUS OF SCADS POPULATION IN THE WATERS OF THE SOUTHERN PART OF THE SUNDA SHELF
}

\author{
Suherman Banon Atmaja*) and Duto Nugroho**)
}

\begin{abstract}
The scads population have long been exploited in Idonesia. Exploitation to the offshore water started when purse seine was introduced in 1970. The exploitation extends eastwards to the Macassar Strait and northwards to the southern part of the South China Sea. The scads (Decapterus russellii) and (Decapterus macrosoma) form the bulk of the catch. Now the scads are exploited in the whole Java Sea. The study describes the geographic repartition of the scads populations, the evolution of the landings linked to the extension of the fishing grounds, and the reproductive biology of these species. Analysis was carried out from commercial landings of the seiners. $D$. macrosoma, an oceanic species where the landings increased a lot when the fishing grounds extended eastwards and dominant from October to Aprii. D. russellii, a neritic species, which form the bulk of the catch since the exploitation started. It inhabits the fishing grounds off the North coast of Java to Masalembo Island and the southern part of South China Sea. For the two species there is a West-East trend in the size. The application of surplus production model revealed significant indications that the level of exploitation already slightly exceeded maximum sustainable yield and since 1992, the catch of scads exceed sustainable yield curve.
\end{abstract}

\section{KEYWORDS: geography, scads distribution, status, Sunda Shelf}

\section{INTRODUCTION}

Since 1970, the development of the exploitation of small pelagic resources in the Sunda Self waters is strongly linked to the introduction and fast booming of the purse seiner fleets. After the trawl banned in 1980 , these fleets became the sole semi industrial exploitation in these waters. Numerous trawlers were transformed to purse seiners. In 1982/1983, the fleets extended their fishing ground towards the eastern part of the Java Sea and the southern part of the South China Sea. This extension was made easier by the introduction of bigger vessels $(80-100$ GT). In $1986 / 1987$, fishing tactic changed, light replaced fish aggregating device (FAD) (rumpon) as the main attraction of fish (Atmaja \& Sadhotomo, 1985; Potier \& Sadhotomo, 1995a), and in 1987 fleets settled in West Kalimantan, based at Pontianak then expanded to Pemangkat in 1990

At least four species of scads are found in Indonesian waters, i.e., Decapterus kurroides, $D$. macarellus, $D$. russellii, and $D$. macrosoma. In the southern part of the Sunda Shelf, the last two species are the main components of small pelagic resources in the area. They represent up to $60 \%$ of the catch (Potier \& Sadhotomo, 1995a). Before the introduction of the purse seiners, $D$. russellii was commonly caught by danish seine fishery (Potier \& Sadhotomo, 1995b). In the South China Sea, the results of survey show the existence of share scads by Indonesian and Thailand around the Natuna groups (Midai island) (Sujastani \& Amin, 1978).

Hardenberg (1938) gave a hypothesis on the distribution of scads populations $D$. russellii in the Java Sea. According to this author, three populations inhabits the Java Sea waters, the first population entering the Java Sea from Flores Sea during the South-East monsoon; the two other populations coming from the West during the North-West monsoon. Among these two populations, the Indian Ocean one enters the Java Sea through the Sunda Strait, the South China Sea one through the Karimata Strait. Part of the East population is resident in the Java Sea and its spawning grounds are close to the Bawean Island.

The present study describes the repartition of the main characteristics of scads populations found in the southern part of Sunda Shelf through the analysis of the scads landings by purse seine net, and their status.

\section{MATERIALS AND METHODS}

Data of length frequency were collected from the commercial catch of purse seiners based in Pekalongan (Central Java) and Pemangkat (West Kalimantan) landing places during period of 1996-1998. Catch and effort data of purse seiners came from Pekalongan and Juana Landing Place during periods of 1976-2004. This data collection was part of the research activities of Research Institute for Marine Fisheries and Java Sea Pelagic Fishery Assessment Project.

Length frequency data were obtained through daily sampling. Sampling procedure is explained in Potier \& Sadhotomo (1991) and presented in Appendix 1. Sampling of the catch must be carried out on board the purse seiner before the fish is sorted by commercial category and by size for sale. In every landing place, two systematically taken from the vessel and the fish hold.

\footnotetext{
Research Institute for Marine Fisheries, Ministry of Marine Affairs and Fisheries Muara Baru, Jakarta

Research Center for Capture Fisheries, Ministry of Marine Affairs and Fisheries, Jakarta
} 
Vessel selection: Only the vessels disembarking the fresh fish were taken as samples, if those are more than five vessels coming from the same fishing zones, other wise only one sample to be taken, and the second sample would be the second order if the vessel is coming from another fishing zones. If the number of landings of the same zone are less than five, only one sample taken in a day.

Fish hold selection, the procedure is the same as for vessels. One basket is taken by fish hold then fish is sorted by species, and counted. For each species, 50 fish are measured, if the number is less all individuals are measured. Total of 1,400 samples were measured, they cover all fishing grounds of the purse seine fishery from the southern part of South China Sea to Makassar Strait.

The purse seine fishery exploits nine fishing grounds. Based on the results of the hierarchic clarification performed by Potier (1998), they were grouped in four areas, namely southern part of South China Sea, Central part of the Java Sea (North of Central Java-Karimunjawa Islands), eastern part of Java Sea (Bawean, Masalembo, Kangean, and Matasiri (slands) and western part of Makassar Strait (Samber gelap, Lumu-lumu, Lari-Larian Islands).

Repartition by weight of the scads catch in each fishing area was calculated from the ratio in weight of each species in the samples. The average length of fish caught was derived from cumulative frequency distribution.

The estimation of the current status of scads fish resources in the Sunda Shelf was based on the existing data from the development of purse seine fishery during 1976-2004. The status of scads was estimated by applying surplus production model (Schaefer model). This model assumes a linier relationship between the catch per unit effort (CPUE) and effort (Gulland, 1961 in Fauzi 1999).

\section{RESULTS}

\section{Spatio Temporal Distribution}

In fisheries statistics, landings of various scads species are recorded as one entry. In fact, significant variations exist between the two species according time of the year and fishing zones. The landings of $D$. macrosoma are high in the eastern part of Java Sea and the Makassar Strait. D. russellii dominates in the western part of the Java Sea and the South China Sea (Figure 1).

Comparing the monthly landings of the two species in the different regions of the Sunda Shelf, it shows two situations: in the southern part of the South China Sea and the western part of the Java Sea, landings of $D$. russellii are highly dominant along the year. In the eastern part of Java Sea and Makassar Strait, that species dominates the landings from May to September, and $D$. macrosoma forming the bulk of the catch from October to April. Then, the extension of fishing grounds towards the East increased the share of $D$. macrosoma in the landings of the purse seine fishery (Figure 2).

\section{Average Sizes of Fish}

In the landings, individuals of the two species range from 5 to $25 \mathrm{~cm}$. However, most of the catch ( $97 \%$ for D. macrosoma, $91 \%$ for D. russellii) consists of fish measuring between $10 \mathrm{~cm}$ and $18 \mathrm{~cm}$ (FI).

The cumulative curves of the size distribution calculated for each region show that the average size increases from the west to the east of the region (Figure 3). Semilar were also reported in the previous studies (Dwiponggo, 1987; Widodo, 1988; Sadhotomo \& Potier, 1995; Potier, 1998)

The study of the main modes confirms the results found with geographic repartition of the average size.

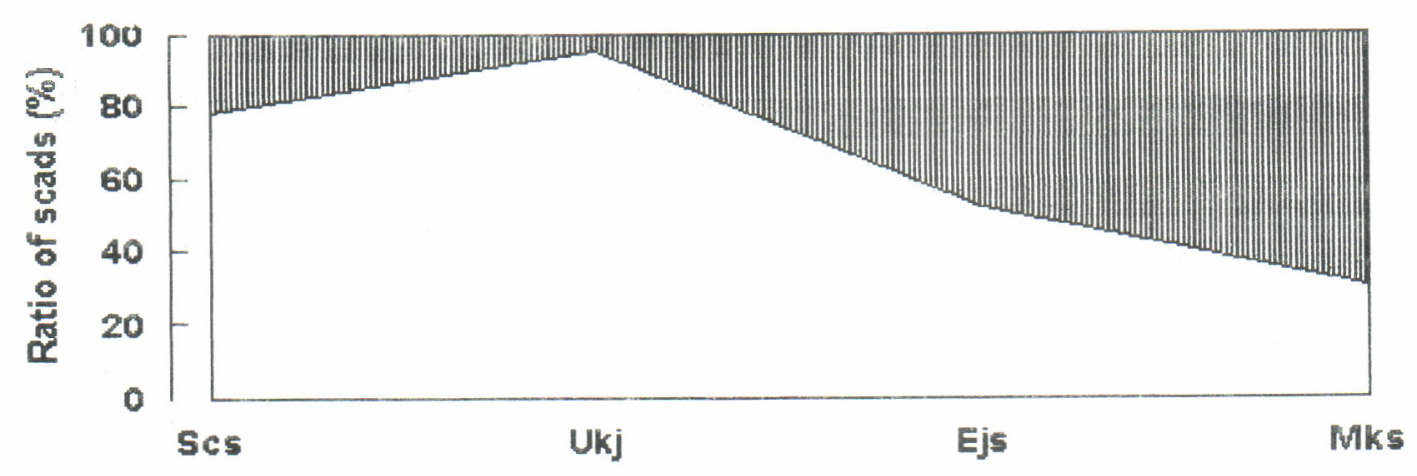

Fishing zones

Figure 1. Ratio of scads D. russellii (below) and D. macrosoma (above) by fishing zones (Remarks: Scs = southern part of South China Sea, Ukj = the north Central Java-Karimunjawa Islands, Esj = eastern part of Java Sea, Mks = western part of Macassar Strait). 
The southem part of South China Set

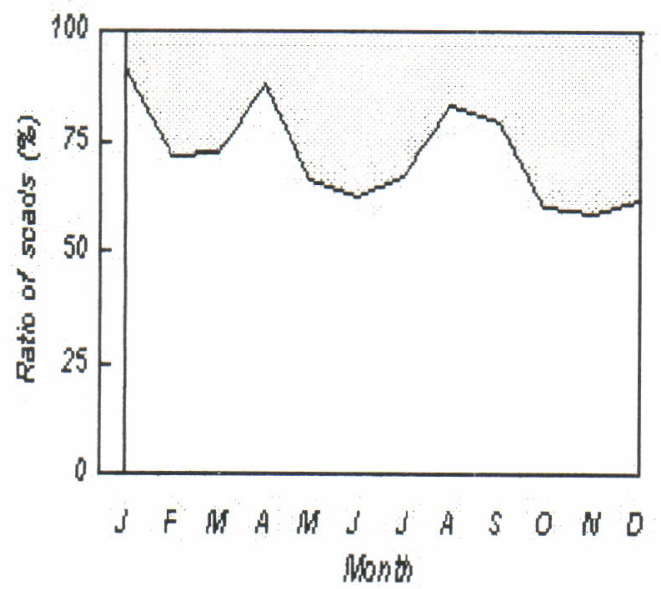

The eastern part of Java Sea

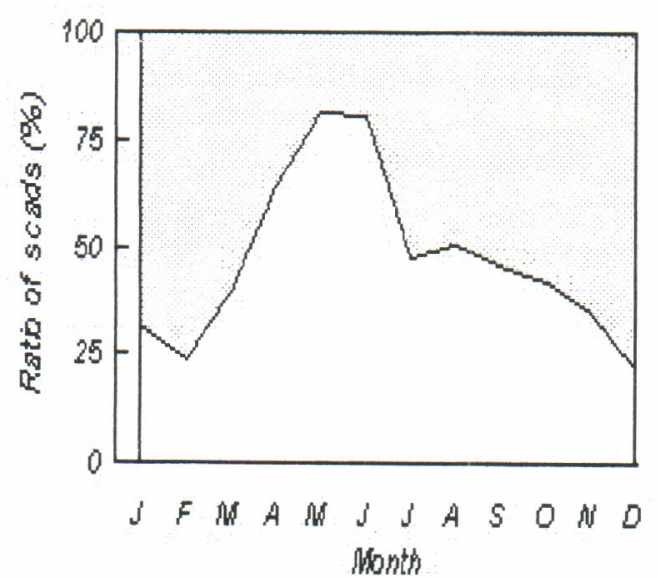

The north Coast of Central Jaya - Karim unjane

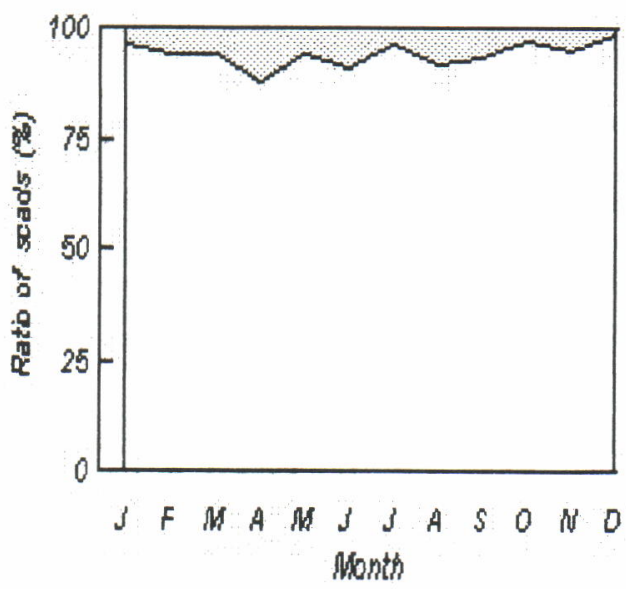

Macassar Strait

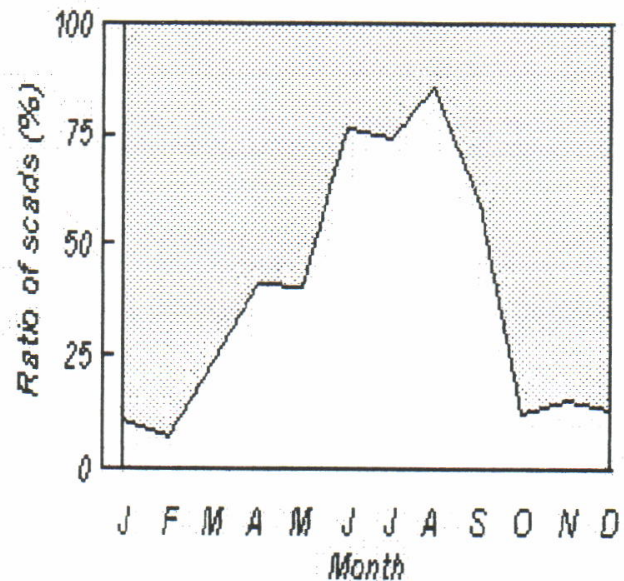

Figure 2. Monthly ratio of scads $D$. russellii (below) and $D$. macrosoma (above) by fishing zones.
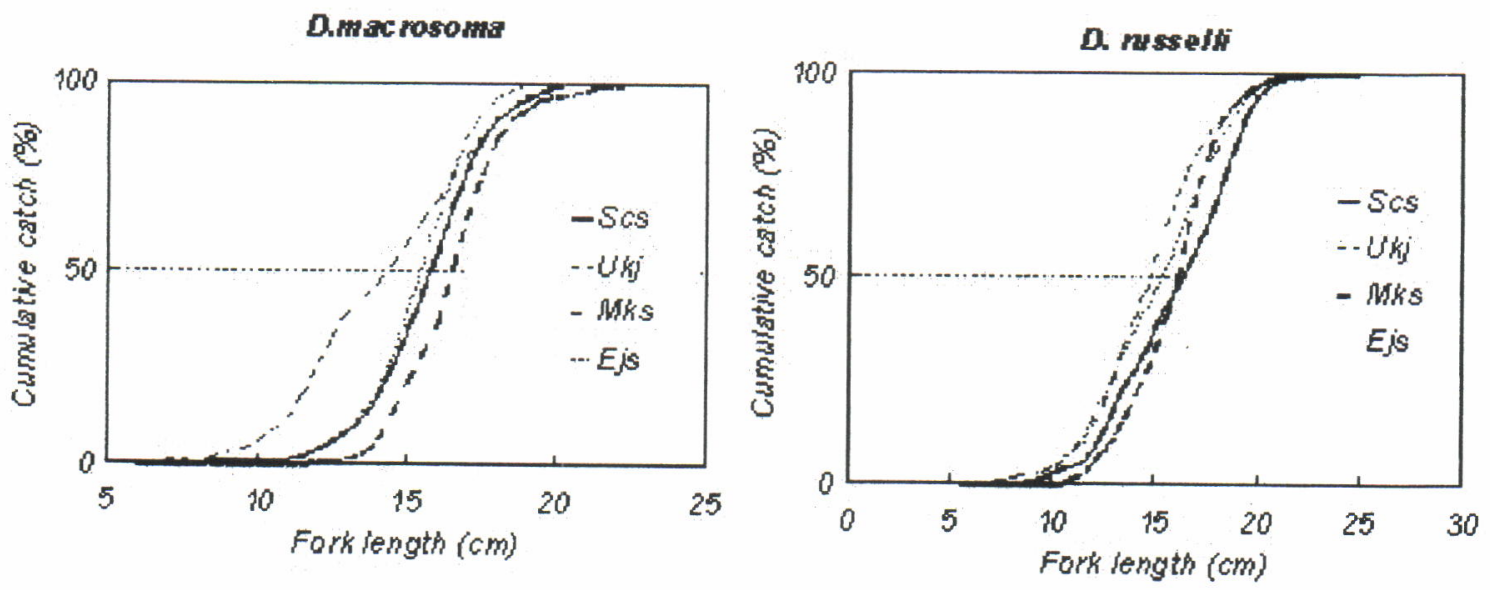

Figure 3. Cumulative length frequency of scads. (Remarks: Scs = southern part of South China Sea, Ukj = Central Java-Karimunjawa Islands, Esj = East of Java Sea, Mks = Macassar Strait) 
The smallest modes are found in the west part of the region and the largest ones in the east. Even, small individuals disappear from the distributions in the east where the largest ones remain alone. In east region, landings of $D$. macrosoma, consist in one mode only. In every region $D$. russellii landings have more modes than D. macrosoma (Figure 4a). Figure 4b showed that average of size was not decreased. It is a possible that the fisher tends to search and to choose fishing ground where was consisted of large size, they take a narrow range of species and size through choice of fishing ground by seasonal.

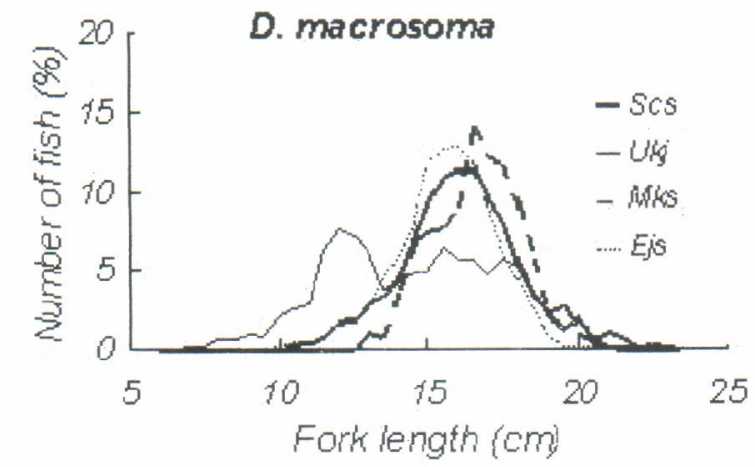

\section{Status of Scads Fishery}

Purse seine fleet was introduced in Indonesia in 1970 , in which north coast of central Java were playing an innovation role of the effective gear on small pelagic fish exploitation. Historical data on the fishery showed that the development of the exploitation of small pelagic resources became offshore, extending their fishing ground toward the eastern part of the Java Sea to the Makassar Strait, is related to dynamic of its fishery which represented through larger fish hold capacity, enlargement of the fishing areas, and rapid changes of

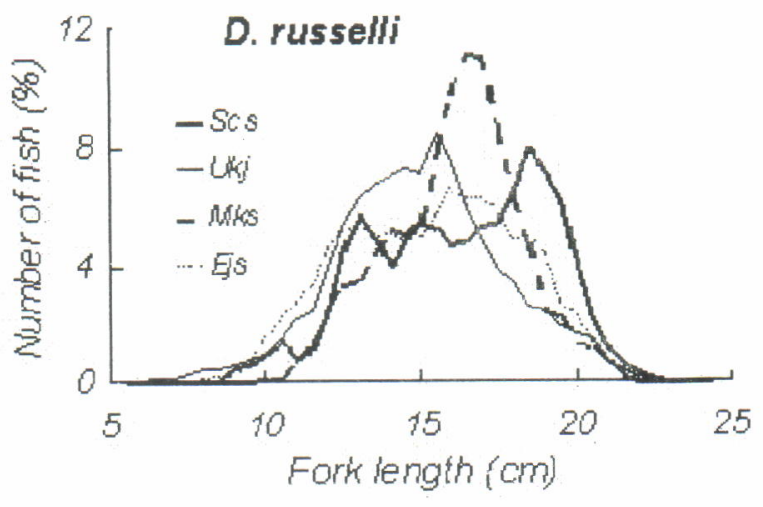

Figure 4a. Length frequency distribution of scads (Remarks : Scs = southern part of South China Sea, Ukj= Central Java-Karimunjawa Islands, Esj = East of Java Sea, Mks = Macassar Strait).

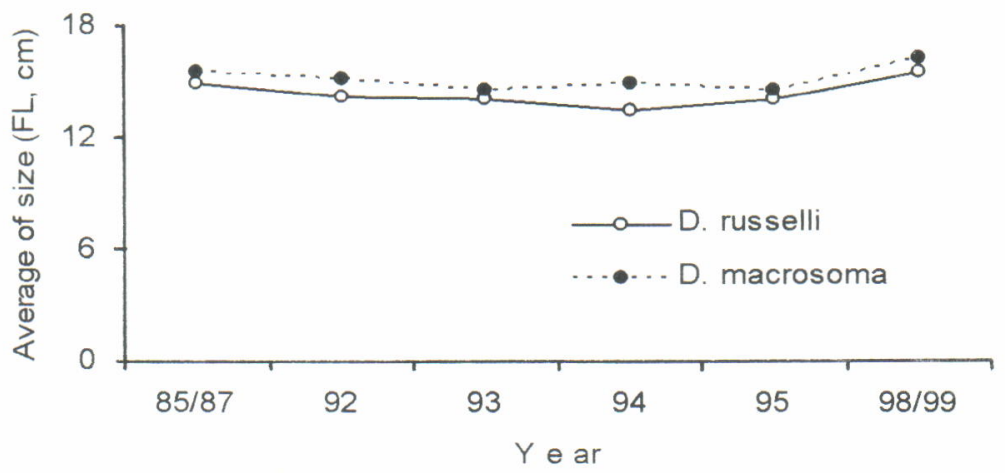

Figure $4 b$. Average of size ( $F L, c m)$.

the fishing strategy. Together with increase in number of large fishing vessels, there was a simultaneous increase in engine capacity of vessels. There was general decrease in the number of vessels with engines less than $120 \mathrm{HP}$, while vessels with 180-320 HP engines showed an increase since 1990, and the most of fishing tactic has used spotlight (Atmaja, 2002). These, in total, increased fishing efficiency per unit effort.

The scads $(D$. russellii and $D$. macrosoma) of genus Decapterus dominated the pelagic fish landings on the Sunda Shelf. Decapterus as single genus contributed $51 \%$ of pelagic fish landings. The catch of pelagic fish and scads showed a declining trend, while fishing days tend to increase (Figure 5).
Catch-effort data in the periods between 1990 to 2004, where the most of fishing tactic used spotlight, were used to estimate the current status of scads fish resources in the Sunda Shelf. The application of surplus production (Schaefer's model) revealed significant indications that the level of exploitation slightly exceeded maximum sustainable yield, and since 1992, the catch of scads exceed sustainable yield curve (Figure 6).

\section{DISCUSSION}

Some authors have already discussed the exploitation of the scads resources in the Sunda Shelf (Sadhotomo et al., 1983; Widodo, 1988, 1989b, 1991; 


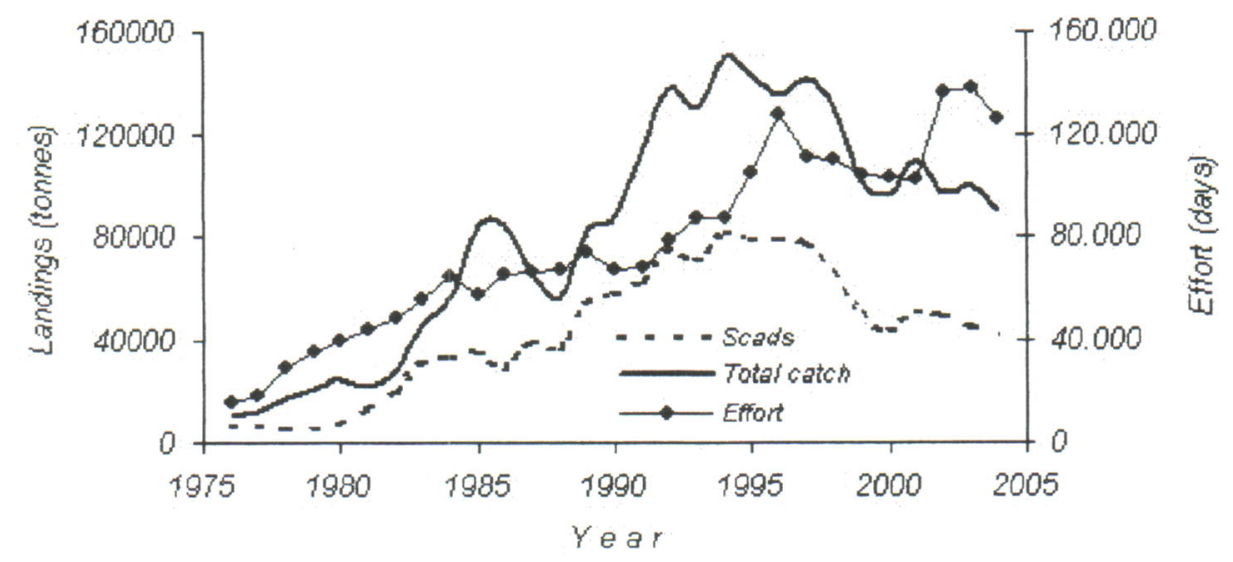

Figure 5. Landing of scads and total catch by purse seines in Pekalongan and Juana.

Figure 6. Relationship between CPUE and effort (left) and Overlapping Sustainable yield curve (Schaefer's production model) and catch-effort during periods 1976-2004.

Potier, 1998; Atmaja 1999). They found that the exploitation was conducted for the most part on immature fish. The bulk of the landings are constituted of fish which are sexually undetermined. In terms of stock dynamics, it is of great importance. Widodo (1989a) suggests that the increases in the exploitation rate will lead to the recruitment overfishing, the size at first capture (Lc) being higher than the size at first maturity (Lm). Other such as Potier (1998) suggests that the exploitation should be made on a small part of the stocks which extend far beyond the limits of the exploitation area.

In the Sunda Shelf, small pelagics are very sensitive to the environmental changes. As a result of the monsoon, the hydrology varies a lot along the year. The salinity is the main factor regulating the distribution of these populations. From our study, $D$. russellii is a resident species of the Java Sea and shows a neritic behaviour, $D$. macrosoma is a more oceanic species and enters the Java Sea during the South-East monsoon when prevailing conditions are optimal. These different behaviors are in agreement with the work of Potier \& Sadhotomo (1995a) on the small pelagic of the Java Sea.

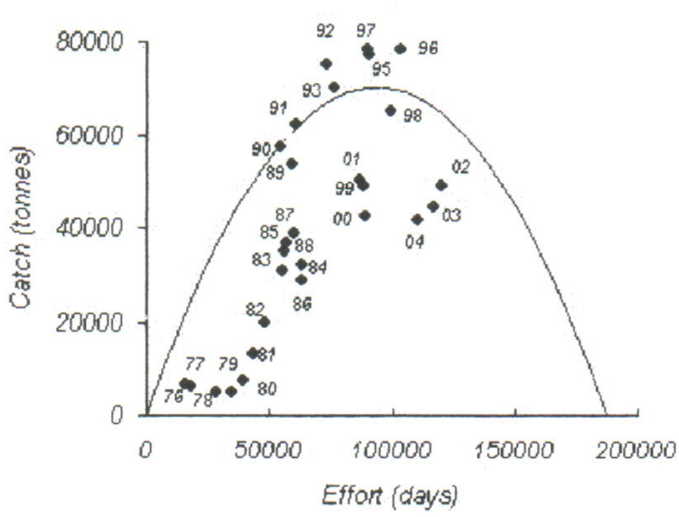

The shift of the exploitation towards eastern part of the Java Sea increased the landings of $D$. macrosoma and other oceanic species. The exploitation is now made on more complex species and less dependent on one species ( $D$. russellii), as previously carried out.

From genetics studies, it seems that $D$. russellii has a wide repartition in the Sunda Self (Perrin, 1998). D. macrosoma should not be presented some difference. The exploitation of the purse seiners seems to be done on two populations: South China Sea, and the eastern one which extends from the Java Sea to Macassar Strait reaching the northern part of Sulawesi (Arnaud, 1998).

Like most Indonesian fisheries, the Java Sea fisheries may be characterized as de facto open access with no restrictions on fishing effort. Free competition occurs among large-scale and small scale fishers. Increasing numbers and sizes of fishing gear and boats, as well as extension of operations into new fishing grounds, have resulted in biological and economic over-exploitation. Over-exploitation, as indicated by the catch of pelagic fish and scads showed a declining trend, while fishing days tend to 
increase. It means that fisher have to stay a longer times at sea for searching fish schooling or they should be oriented on the successful of their trip. Substitution fleet as responds to diminution of stock pelagic fish, some purse seiner vessels turn to denish seine for demersal fishing (the demersal resources of the Java Sea have recovered during twenty year of the trawl ban and now represent an underutilized resource). These indicated that purse seine fishery has decreased in CPUE and profit per vessel. Since 2002, the increase in landings of leather jacket (Alesterus monoceros) when peak season of scads also signal the unhealthy status of the pelagic fishery. The pelagic fishery recourses including the scads resources are over-exploited on Sunda Shelf, thus stringent management measure should be formulated and enforced to ensure sustainability. At least access restriction to the fishery for new vessels and the matter of controlling fishing tactic, especially amount of spotlight.

\section{CONCLUSION}

The species of scads form the bulk of the purse seiners landings. They have a big economic input on the fisheries of the northern coast of the Java Island.

Since the fisheries extended eastward, the percentage of $D$. macrosoma increases in the landings. Nowadays, there is a balance among the species in the catch of purse seiners. Most of the catch consists of immature individuals. Such practice can endanger the stocks sustainability. However, as the exploitation is conducted on more complex species, where some populations are exploited on part of the stock only, the system has a strong resilience.

The management of pelagic fisheries should focus on the interaction of the large-scale and small scale fishers. The proposals for the scads management should as far as possible adopt an integrated approach to incorporate biological, environmental and socioeconomic aspects.

\section{REFERENCES}

Arnaud, S. 1998. Le chinchard, Decapterus macrosoma, poisson pélagique de Mer de Java un exemple d'espèce marine génétiquement structurée. Mem., DEA., USTL-ENSAM, Montpellier, $21 \mathrm{p}$

Atmaja, S.B. \& B. Sadhotomo. 1985. Operasional aspects of purse seiner in the Java Sea. J. Mar. Res. Inst., 32, 65-71 (Indonesian).

Atmaja, S.B., B. Sadhotomo, \& Suwarso. 1995. Reproduction of main small pelagic species in the Java Sea. In: Potier M. \& S. Nurhakim (Eds.), Biology, Dynamics and Exploitation of small pelagic in Java Sea (BIODYNEX). AARD/ ORSTOM. 69-84.

Atmaja, S.b. lyyg. Variasi geografis hasil tangkapan ikan layang (Decapterus spp.) di perairan bagian selatan Paparan Sunda. Jur. Pen. Per. Ind. Vol V (3): 63-71

Atmaja. 2002. Dinamika perikanan purse seind di Laut Jawa dan sekitarnya. Tesis. IPB.64p.

Bayer, J.E. 1987. On length-weight relationships. Part I: Computing the mean weight of fish in a given length class. Fishbyte. ICLARM, Vol 5(1), 11-13.

Dwiponggo, A., T. Hariati, S.B. Atmaja, Pelamores M.I. \& Pauly, D. 1987. Growth, mortality, and recruitment of commercially important fish and Penaed shrimps in Indonesian waters. ICLARM, Tech. Paper. 17. RAMF Jakarta. ICLARM Manila.

Fauzi, A. 1999. An econometric analysis of the surplus production model and its application for tropical fisheries. Working paper. Institute Fisheries Analysis, Simon Fraser University. British Columbia, Canada. $19 \mathrm{p}$.

Hardenberg, J.D.F. 1938. Theory on the migration of layang (Decapterus spp.) in the Java Sea. Med Inst. Zeevisscherij, Batavia, 124-131

King, M. 1998. Fisheries biology, assessment and management. Fishing News Books, England $338 \mathrm{p}$.

Perrin, C. 1998. Phylogénie de l'ADN mitochondrial structure géographique et reconstruction de l'histoire évolutive des populations du complexes d'espèce Decapterus cf. russellii dans le sud-est asiatique. Mem., DEA., Univ., Mediterranee AixMarseille II, $43 \mathrm{p}$.

Potier, M. \& B, Sadhotomo. 1991. Sampling training ALAINS/87/17. Scien. and Tech. Doc., 4, $29 p$

Potier, M. \& B, Sadhotomo. 1995a. Exploitation of the large and medium seiners fisheries. In: Potier M. \& S. Nurhakim (Eds.), Biology, Dynamic and Exploitation (BIODYNEX). AARD/ORSTOM, 195214.

Potier, M. \& B, Sadhotomo. 1995b. Trends in the scad fishery of the Java Sea exploitation of the large and medium seiners fisheries. Fourth Asian Fisheries Forum, Beijing: 16-20 October 1995.

Potier, M. 1998. Pëcherie de layang et senneurs semi industriels Javanais: Perspective historique et approche système. Phd Thesis, Université de Montpellier II, $280 \mathrm{p}$. 
Sadhotomo, B., S.B. Atmaja, \& S. Nurhakim. 1983. Estimation of growth parameters, instataneous mortality and yield per recruit of scad, Decapterus maruadsi (Temminck, Schlegel) in the Java Sea. J. Mar. Res. Inst., 27, 1-9.

Sadhotomo, B. \& M. Potier. 1995. Exploratory scheme for recruitment and migration of main Pelagic species in the Java Sea. In: Potier M. \& $S$. Nurhakim (Eds.), Biology, Dynamic and Exploitation (BIODYNEX). AARD/ORSTOM, 155184.

Sadhotomo, B. 1998. Bioécologie des principales espèces pélagiques exploitées en mer de Java. Phd Thesis, Université de Montpellier II, 364 p.

Sujastani, T. \& E.M. Amin 1978. Kemungkinan pengembangan dan modernisasi perikanan skala kecil atau perikanan rakyat di perairan Laut Cina Selatan yang termasuk kawasan Kabupaten Kepulauan Riau. Simposium Mordernisasi Perikanan Rakyat. LPPL. Litbang Pertanian. 26 p.

Suwarso, 1993. Length-weight relationships of the main pelagic fishes of Java Sea. ALA/INS/87/17. Scien. and Tech. Doc., 10, $22 \mathrm{p}$.
Widodo. J. 1988. Population dynamics and management of "ikan layang", scad mackerel, Decapterus spp. (Pisces Carangidae) in the Java Sea. PhD dissertation School of Fisheries, University of Washington, Seattle. $150 \mathrm{p}$

1989a. Preleminary assessment of effects of changes in size limit and fishing intensity on small pelagic multi-species in the Java Sea. J. Mar. Res. Inst., 51, 67-78.

1989b. Reproductive biology and harvesting strategy of Indian scad Decapterus russelli (Ruppel, 1830) (Pisces: Carangidae) of the Java Sea. J. Mar. Res. Inst., 53, 89-96.

1991. Maturity and spawning of shortfin scad (Decapterus macrosoma, Carangidae) of the Java Sea. Asian Fish. Sci., 4, 245-252.

1997. Review of small pelagic fisheries of Indonesia. In: Devaraj, M. \& P. Martosubroto (Eds.). Small pelagic resources and their fisheries in the Asian-Pacific region. Proceeding of APFIC working party on marine fisheries, 13-16 May 1997. Bangkok, Thailand. RAP Publication. 1997/31. 199-226. 
Appendix 1. Sampling scheme for purse seiner catch in landing place of Pekalongan and Pemangkat

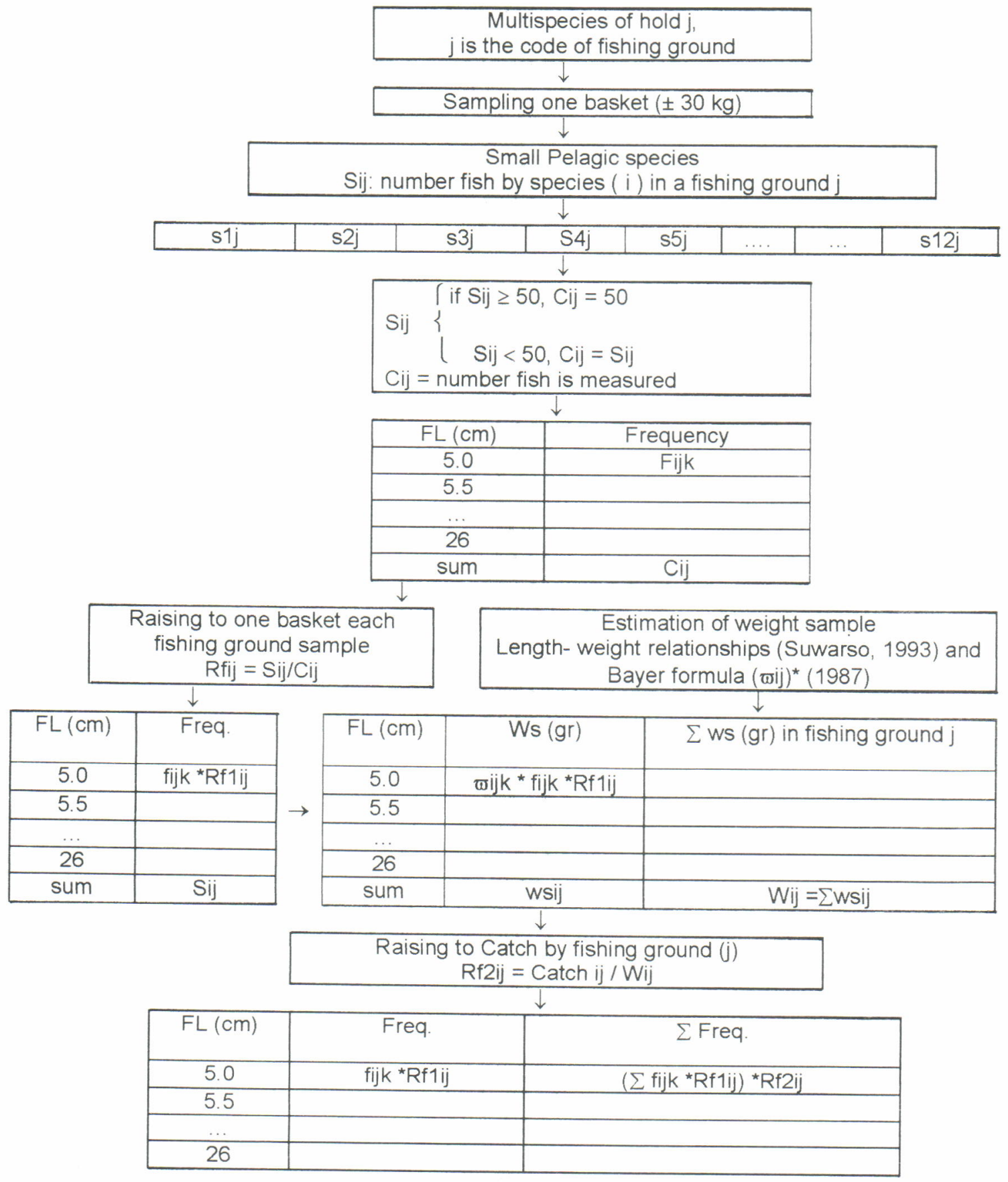

$\left.{ }^{\star}\right)$ שijk $=1 /\left((k+0.25)-(k-.25)^{\star} 1 /(b+1)^{\star}\left((k+.25)^{b+1}-(k-.25)^{b+1}\right)(\right.$ Bayer, 1987), $k$ is class of $F L, W s=$ weight of sample 